Journal of Applied Pharmaceutical Science Vol. 5 (06), pp. 050-053, June, 2015

Available online at http://www.japsonline.com

DOI: $10.7324 / \mathrm{JAPS} .2015 .50607$

ISSN 2231-3354 (cc)) EY-NC-SA

\title{
Bacteriostatic and Bactericidal Profile of Leaves and Twigs Essential oils of Moroccan Pistadia lentisaus L.
}

\author{
Taoufik Haloui ${ }^{1,2^{*}}$, Abdellah Farah ${ }^{2}$, Mounyr Balouiri ${ }^{3}$, Marwa Chraibi ${ }^{3}$, Mouhcine Fadil ${ }^{1}$, Kawtar Fikri Benbrahim ${ }^{3}$, \\ Aziz Belrhiti Alaoui ${ }^{1}$ \\ ${ }^{1}$ Laboratory of Functional Ecology and Environment, Faculty of Sciences and Technology, Sidi Mohamed Ben Abdellah University, BP 2202 - Road \\ Imouzzer. Fez, Morocco. ${ }^{2}$ Laboratory of Aromatic Plants, Medicinal and Natural Substances, National Institute of Medicinal and Aromatic Plants, Sidi \\ Mohamed Ben Abdellah University, P.O. Box 159. Taounate, 34025, Morocco. ${ }^{3}$ Laboratory of Microbial Biotechnology, Faculty of Science and \\ Technology Saïss. Sidi Mohamed Ben Abdellah University, P.O.Box 2202. Fez, Morocco.
}

\section{ARTICLE INFO \\ Article history: \\ Received on: 01/05/2015 \\ Revised on: 18/05/2015 \\ Accepted on: 26/05/2015 \\ Available online: $27 / 06 / 2015$}

\section{Key words:}

Essential oil, Pistacia

lentiscus, antibacterial

activity, bacteriostatic, bactericidal.

\begin{abstract}
In order to increase the Moroccan Pistacia lentiscus L. value, the antibacterial activity of its twig's and leave's essential oils was evaluated. The study of antibacterial activity was performed on Gram positive bacteria Bacillus subtilis, Staphylococcus aureus and Gram-negative bacteria Escherichia coli, Pseudomonas aeruginosa by the microdilution method. The minimal inhibitory concentration (MIC) and minimal bactericidal concentration $(\mathrm{MBC})$ values of leaves and twigs essential oils against the four studied strains were determined and showed that both essential oils tested have remarkable antibacterial activity. Bacillus subtilis was the most sensitive strain against the two essential oils while Pseudomonas aeruginosa was the most resistant one.
\end{abstract}

\section{INTRODUCTION}

For centuries, medicinal plants have been used as a remedy for various diseases. Over the past few years, the use of plant-based natural antimicrobials in the treatment of bacterial infections has gained much recognition (Kasrati et al., 2014).The progressive interest of these plant's use has urged researchers to look for new methodologies (Hemaiswarya et al., 2008), and for suitable design to develop new therapeutic value products with highly effective anti-infective agents in general and antibacterial agents in particular (Turgis et al., 2012).

Pistacia lentiscus L. belong to the family of Anacardiaceae, also called pistachio mastic or mastic tree (Hmamouchi et al., 1999). Shrub up to $5 \mathrm{~m}$ high, the mastic is one of the most characteristic trees of the Mediterranean region (Aafi et al, 2002), which grows on all kinds of soil (Bayer et al., 2009) and it is a native species of Morocco (Aafi et al, 2002). The therapeutic properties of this species were known, long time

* Corresponding Author

Email: taoufik.haloui@gmail.com ago, when the Egyptians used mastic for embalming (De Pooter et al., 1991). The essential oil of mastic tree has been shown to have antibacterial (Derwich et al., 2010), anti-fungal (Darua et al., 2003), insecticides (Bachrouch et al., 2010) and antioxidants effects (Barra et al., 2007). Mastic tree is also used in cosmetics, perfumes and as a flavoring in food preparations (Daferera et al., 2002). The aim of this study was to evaluate the antibacterial activity and to identify the chemical profiles of essential oils from twigs and leaves of Pistacia lentiscus L. collected in Taounate region (Morocco).

\section{MATERIAL AND METHODS}

\section{Plant material}

Leaves and twigs of $P$. lentiscus $\mathrm{L}$. were randomly collected from natural populations at the flowering stage during May 2013 in the Ifrane's forest at Taounate region in Morocco (Altitude: $475 \mathrm{~m}, 34^{\circ} 35^{\prime} 12.5^{\prime \prime} \mathrm{N} 4^{\circ} 38^{\prime} 31.1^{\prime \prime} \mathrm{W}$ ). Pistacia lentiscus leaves were separated from stem, and the twigs were cut into small pieces to facilitate the extraction of essential oils. 


\section{Extraction of essential oil}

The essential oils were extracted from P. lentiscus L. by hydrodistillation process in Clevenger-type apparatus (Clevenger, 1928). Plant material was dried at $105^{\circ} \mathrm{C}$ for 4 hours to determine the moisture (Zrira et al., 1995) and the yield was expressed relatively to the dry matter. Essential oils obtained were stored in opaque glass bottles at $4{ }^{\circ} \mathrm{C}$.

\section{Chemical analysis of essential oil}

The essential oil was analyzed using Gas chromatography (GC) coupled to mass spectrometry GC / MS (Polaris Q ion trap MS). Hence, analyses were performed on a Hewlett-Packard (HP 6890) gas chromatograph (FID), equipped with a $5 \%$ phenyl methyl silicone HP-5 capillary column $(30 \mathrm{~m} x$ $0.25 \mathrm{~mm} \times$ film thickness $0.25 \mu \mathrm{m})$. The temperature was programmed from $50^{\circ} \mathrm{C}$ after $5 \mathrm{~min}$ initial hold to $200^{\circ} \mathrm{C}$ at $4^{\circ} \mathrm{C} / \mathrm{min}$. Chromatography carrier gas was $\mathrm{N} 2(1.8 \mathrm{ml} / \mathrm{min})$, split mode was used (Flow: $72.1 \mathrm{ml} / \mathrm{min}$, ratio: 1/50), temperature of injector and detector was $250{ }^{\circ} \mathrm{C}$, final hold time was $48 \mathrm{~min}$. The machine was led by a computer system type "HP Chem Station", managing its functioning and allowing to follow the evolution of chromatographic analyses. Diluted samples (1/20 in methanol) of $1 \mu 1$ were injected manually.

\section{Antibacterial activity \\ Bacterial strains}

The in vitro antibacterial effect of essential oils was tested against the following bacterial strains: Pseudomonas aeruginosa ATCC 27853, Bacillus subtilis ATCC 3366, Staphylococcus aureus ATCC 29213 and Escherichia coli ATCC 25922. All of these strains were maintained in $20 \%$ glycerol at $20{ }^{\circ} \mathrm{C}$ as stock.

\section{Inoculum preparation}

The direct colony suspension method was used for the inoculum preparation. Briefly, bacteria were sub-cultured in the Luria Bertani agar (LB). Plates were incubated at $37{ }^{\circ} \mathrm{C}$ for $24 \mathrm{~h}$. A loop full of isolated colony was aseptically transferred into physiologic saline solution and the turbidity of the suspension was adjusted to 0.5 McFarland (Murray et al., 2007).

\section{Antibacterial screening}

The screening of antibacterial activity was performed by the agar disc-diffusion method (Murray et al., 2007). Petri dishes (90 $\mathrm{mm}$ in diameter) containing LB- agar were seeded using the previously prepared inoculum. The seeding was done so as to ensure a homogeneous distribution of bacteria, then excess liquid was eliminated with a Pasteur pipette and the Plates were dried for 20 minutes. The sterile filter paper discs $(6 \mathrm{~mm}$ in diameter) were individually soaked with $10 \mu \mathrm{l}$ of each essential oil then placed on the surface of plates seeded, which were placed at $4{ }^{\circ} \mathrm{C}$ for $2 \mathrm{~h}$. After incubation for $24 \mathrm{~h}$ at $37{ }^{\circ} \mathrm{C}$, inhibition diameters were measured. All the tests were performed in triplicate.
Determination of the minimum inhibitory concentration (MIC) and minimum bactericidal concentration (MBC)

The broth microdilution method was used to evaluate the minimum inhibitory concentration (MIC) according to the CLSI guidelines M7-A7 (CLSI, 2007), with slight modifications. Briefly, agar at $0.15 \%(\mathrm{w} / \mathrm{v})$ was used as emulsifier and resazurin was used as bacterial growth indicator (Mann and Markham, 1998). Firstly, $50 \mu \mathrm{l}$ of Mueller Hinton Broth (MHB) supplemented with bacteriological agar $(0.15 \% \mathrm{w} / \mathrm{v})$ were distributed from the second to the 12th well of a 96-well polypropylene microtitre plate. Essential oils dilutions were prepared in MHB supplemented with agar $(0.15 \% \mathrm{w} / \mathrm{v}), 100 \mu \mathrm{l}$ of these suspensions were added to the first test well of each microtitre line, then $50 \mu \mathrm{l}$ of scalar dilution were transferred from the second to the 11 th well. The $12^{\text {th }}$ well was considered as growth control. Then, $50 \mu \mathrm{l}$ of a bacterial suspension was added to each well at a final concentration of approximately $10^{6} \mathrm{CFU} / \mathrm{ml}$. The final concentration of the essential oil was between 16 and $0.0015 \%(\mathrm{v} / \mathrm{v})$ for leaves and twigs. After incubation at $37^{\circ} \mathrm{C}$ for $20 \mathrm{~h}, 5 \mu \mathrm{l}$ of resazurin was added to each well (Mann and Markham, 1998). After further incubation at $37^{\circ} \mathrm{C}$ for $2 \mathrm{~h}$, the MIC was determined as the lowest essential oil concentration that prevented a change in resazurin color (CLSI, 2007). Experiments were conducted in triplicate.

To determine the minimum bactericidal concentration (MBC), $2 \mu \mathrm{L}$ of each negative well, in which microbial growth was not observed, were spotted on LB plates and incubated at 37 ${ }^{\circ} \mathrm{C}$ for $24 \mathrm{~h}$. The MBC corresponded to the lowest concentration of the essential oil at which the incubated microorganism was completely killed (Bassole et al., 2001). Each test was performed in triplicate.

\section{RESULTS AND DISCUSSION}

\section{Yield and chemical composition of the leaves and twigs essential oils}

The hydrodistillation of Pistacia lentiscus leaves and twigs gave essential oils with yields of $0.3 \%$ and $0.5 \%(\mathrm{v} / \mathrm{w})$ respectively.

The results of chromatographic analysis of Pistacia lentiscus leaves and twigs essential oils are presented in Table 1. In order to simplify the analysis of the results, only compounds having abundance more than $0.5 \%$ were selected. Twenty nine compounds, which represented $77.90 \%$ of the total leaves essential oils, were identified. The major constituents of the Pistacia lentiscus leave's essential oil were Tricyclene (7.71\%), terpinen-4ol $(7.44 \%)$, sabinene $(6.96 \%)$, caryophyllene $(6.62 \%)$, caryophyllene oxide $(6.05 \%)$, p-cymene (5.04 \%), 3-carene (4.44\%), $\alpha$-terpineol (4.16\%) and trans- $\beta$-Ocimene (3.89\%).

Twenty six compounds, which represented $84.72 \%$ of the twigs essential oils, were identified. The major constituents of this essential oil were $\alpha$-pinene $(19.24 \%)$, tricyclene $(8.16 \%)$, trans- $\beta$ Ocimene $(6.9 \%)$, caryophyllene $(6.18 \%), 3$-carene $(5.18 \%)$ and germacrene $(5.17 \%)$. Similar compounds have been reported at 
different percentages by other authors (Amhamdi et al., 2009). However, the number of compounds identified in leaves and twigs essential oil (29 and 26) respectively, was inferior to the number of compounds identified in a previous study (Hafsé et al., 2013). This could be explained by: environmental factors such as geography, temperature and collection period, etc., which were considered to play a key role in the chemical composition of essential oils (Derwich et al., 2010).

Table 1: Main constituents (\%) of Pistacia lentiscus leaves and twigs essential oil.

\begin{tabular}{|c|c|c|c|}
\hline $\mathbf{R I}(\min )^{a}$ & Compound $^{b}$ & Leaves ( \%) & Twigs (\%) \\
\hline 915 & Tricyclene & 7.71 & 8.16 \\
\hline 939 & $\alpha$-Pinene & - & 19.24 \\
\hline 953 & Camphene & 1.65 & 1.21 \\
\hline 974 & Sabinene & 6.96 & - \\
\hline 1006 & $\alpha$-Phellandrene & 2.61 & 3.36 \\
\hline 1011 & 3-carene & 4.44 & 5.18 \\
\hline 1026 & p-Cymene & 5.04 & 3.52 \\
\hline 1050 & trans- $\beta$-Ocimene & 3.89 & 6.90 \\
\hline 1072 & $\gamma$-Terpinene & 0.63 & - \\
\hline 1089 & p-Cymenene & 0.59 & 0.55 \\
\hline 1180 & Terpinen-4-ol & 7.44 & 0.86 \\
\hline 1192 & $\alpha$-Terpineol & 4.16 & 0.65 \\
\hline 1195 & Myrtenal & - & 0.50 \\
\hline 1219 & Trans-Carveol & 0.62 & 0.56 \\
\hline 1266 & Geraniol & 0.58 & - \\
\hline 1288 & Bornylacetate & 3.32 & 1.96 \\
\hline 1294 & Undecanone & 0.80 & 0.62 \\
\hline 1348 & $\alpha$-Cubebene & 1.06 & 1.21 \\
\hline 1381 & $\alpha$-Copaene & 0.83 & - \\
\hline 1395 & $\beta$-Elemen & 0.94 & 1.74 \\
\hline 1418 & Caryophyllene & 6.62 & 6.18 \\
\hline 1454 & $\alpha$-Caryophyllene & 1.65 & 1.75 \\
\hline 1462 & Benzoic acid, pentyl ester & 0.57 & - \\
\hline 1464 & Aromadendrene & 0.65 & 0.85 \\
\hline 1480 & Germacrene- D & - & 5.17 \\
\hline 1499 & $\alpha$-Muurolene & 1.83 & 1.84 \\
\hline 1513 & $\gamma$-Cadinene & 0.68 & 1.76 \\
\hline 1523 & Calamenene & 0.80 & - \\
\hline 1528 & $\delta$-Cadinene & 1.97 & 3.98 \\
\hline 1538 & $\alpha$-Cadinene & 1.90 & - \\
\hline 1576 & Spathulenol & - & 0.86 \\
\hline 1581 & Caryophylleneoxide & 6.05 & 2.29 \\
\hline 1648 & Aromadendreneoxide & - & 3.82 \\
\hline 1652 & $\alpha$-Cadinol & 2.72 & - \\
\hline
\end{tabular}

a: retention indices on HP-5 capillary column.

b: Compounds present in trace amounts $(<0.5 \%)$ were not registered.

\section{Antibacterial activity}

Results of both essential oil's antibacterial activity against $S$. aureus, E. coli, B. subtilis and $P$. aeruginosa are shown in table 2. As can be noted in this finding, both essential oils tested have shown a remarkable antibacterial effect. So, crude essential oils of the two Pistacia lentiscus parts were active against all strains examined. Indeed, the MIC values ranged from 4 to $0.015 \%(\mathrm{v} / \mathrm{v})$ for leave's essential oil and from 16 to $0.5 \%(\mathrm{v} / \mathrm{v})$ for twig's essential oil. Hence, leaves essential oil exhibit a higher antibacterial effect with MIC values $0.015,0.5,1$ and $4 \%$ fold least compared to twigs essential oil with MIC values $0.5,4,4$ and $16 \%$ against $B$. subtilis, $S$. aureus, $E$. coli and $P$. aeruginosa respectively. Also, it can be noted that E. coli and $P$. aeruginosa (Gram- negative) were more resistant to the leaves and twigs essential oil compared to $S$. aureus and B. subtilis (Gram-positive).
Regarding the MBC values of both essential oils tested (Table 3), we found that MBC values could well be similar to their MIC values against $P$. aeruginosa and $B$. subtilis and two fold higher toward $S$. aureus and $E$. coli for twigs essential oil. In addition we noted that MBC values were 2, 4, 8 and 2 fold higher toward $B$. subtilis, $S$. aureus, E. coli and $P$. aeruginosa respectively than MIC for leaves essential oil.

Table 2: Determination of minimum inhibitory concentration (MIC) values of $P$. lentiscus essential oils against bacteria tested.

\begin{tabular}{cccccccccc}
\hline Concentration & \multicolumn{4}{c}{ Leaves essential oil } & \multicolumn{5}{c}{ Twigs essential oil } \\
\hline$\%$ & B. s & S. a & E. c & P. a & B. s & S. a & E. c & P. a \\
\hline 16 & - & - & - & - & - & - & - & - \\
8 & - & - & - & - & - & - & - & + \\
4 & - & - & - & - & - & - & - & + \\
2 & - & - & - & + & - & + & + & + \\
1 & - & - & - & + & - & + & + & + \\
0.5 & - & - & + & + & - & + & + & + \\
0.25 & - & + & + & + & + & + & + & + \\
0.125 & - & + & + & + & + & + & + & + \\
0.062 & - & + & + & + & + & + & + & + \\
0.031 & - & + & + & + & + & + & + & + \\
0.015 & - & + & + & + & + & + & + & + \\
\hline
\end{tabular}

B. s: Bacillus subtilis, E. c: Escherichia coli, S. a: Staphylococcus aureus, P. a: Pseudomonas aeruginosa

Table. 3: Determination of minimum bactericidal concentration (MBC)values of $P$. lentiscus essential oils against bacteria tested.

\begin{tabular}{ccccccccc}
\hline Concentration & \multicolumn{4}{c}{ Leaves essential oil } & \multicolumn{5}{c}{ Twigs essential oil } \\
\hline$\%$ & B. $\mathbf{s}$ & S. a & E. c & P. a & B. s & S. a & E c & P. a \\
\hline 16 & - & - & - & - & - & - & - & - \\
8 & - & - & - & - & - & - & - & + \\
4 & - & - & + & + & - & + & + & + \\
2 & - & - & + & + & - & + & + & + \\
1 & - & + & + & + & - & + & + & + \\
0.5 & - & + & + & + & - & + & + & + \\
0.25 & - & + & + & + & + & + & + & + \\
0.125 & - & + & + & + & + & + & + & + \\
0.062 & - & + & + & + & + & + & + & + \\
0.031 & - & + & + & + & + & + & + & + \\
0.015 & + & + & + & + & + & + & + & + \\
\hline
\end{tabular}

B. s: Bacillus subtilis, E. c: Escherichia coli, S. a: Staphylococcus aureus, P. a: Pseudomonas aeruginosa

Antimicrobial activity of the essential oils of P. lentiscus against tested bacteria has shown that Gram-negative strains were more resistant compared to the Gram- positive ones. Similar findings have been reported by other authors (Hafsé et al., 2013) who found that Gram negative strains were less sensitive to this essential oil than Gram- positive strains.

Pseudomonas aeruginosa has shown low sensitivity with MIC values of 16 and $8 \%$ for leaves and twigs essential oils respectively. Similarly, previous investigations showed that this bacterial strain was more resistant to leaves essential oils of $P$. lentiscus (Benhammou et al., 2008). Typically, Gram-negative bacteria are more resistant to essential oils than Gram-positive bacteria, due to the differing structures of their cell wall. Outer membrane of the Gram-negative bacteria contains primarily lipopolysaccharides molecules and forms a hydrophilic barrier conferring protection against the effects of highly hydrophobic compounds (Trombetta et al., 2005). The mechanism of action 
assigned at both essential oils has not been studied in detail in the past. The results of this study confirm the findings in previous reports, which state that the strength and spectrum of activity varied between Gram type of target bacteria and the investigated parts of P. lentiscus (Djenane et al., 2011).

The antibacterial activity of the essential oils of $P$. lentiscus could be attributed to their high content of different groups of chemical compounds known for their antibacterial effect. Nevertheless, the antibacterial activities of the essential oils are difficult to correlate to a specific compound due to their complexity (Mélanie et al., 2012). The low antibacterial activity of twigs essential oil compared to the leaves one could be explained by their high content on terpene ( $\alpha$-pinene, tricyclene, 3-carene, trans- $\beta$-Ocimene and D-germacrene) known for their relatively low antibacterial activity (Inouye et al., 2001). Moreover, many reports have shown that $\alpha$-terpineol, present with high percentage in leaves essential oil, exhibit an inhibitory effect against $E$. coli (Alessandra et al., 1999). Similarly geraniols, present only in the leaves oil, exhibit a higher antibacterial effect (Antonio et al., 2007).

\section{CONCLUSION}

This work aims to evaluate the bacteriostatic and bactericidal profile of essential oils of leaves and twigs of Pistacia lentiscus L.against B. subtilis, $S$. aureus, E. coli and $P$. aeruginosa. Both studied essential oils presented remarkable antibacterial activity against tested strains. $B$. subtilis was the most sensitive strain in regard to the two essential oils while $P$. aeruginosa was the most resistant strain. The high antibacterial performance of Pistacia lentiscus essential oils from leaves and twigs should be studied in more details in order to make them a promising antibacterial agent for the control in food and pharmaceutical industries.

\section{REFERENCES}

Aafi A, Taleb MS, Fechtal M. 2002. Espèces, remarquables de la flore du Maroc. Maroc: Centre National de la Recherche Forestière. p. 34.

Amhamdi H, Aouinti F, Wathel et JP, Elbachir A. Chemical Composition of the Essential Oil of Pistacia lentiscus L. from Eastern Morocco. Records of Natural Products 2009; 2: 90- 95.

Bachrouch O, Ben JemâaJM, Aidi WW, Thierry T, Brahim M, Manef A. Composition and insecticidal activity of essential oil from Pistacia lentiscus L. against Ectomyelois ceratoniae Zeller and Ephestia kuehniella Zeller (Lepidoptera: Pyralidae). Journal of Stored Products Research, 2010; 46: 242-247.

Barra A, Coroneo V, Dessi S, Cabras P, Angioni A.Characterization of the volatile constituents in the essential oil of Pistacia lentiscus $L$. from different origins and its antifungal and antioxidant activity. Journal of agricultural and food chemistry 2007; 17: 7093- 7098.

Bassole HN, Kabore ZI, Traore AS.Etude des profils bactériostatiques et bactéricides d'extraits végétaux vis-à-vis de germes pathogènes impliqués dans la contamination des denrées alimentaires d'origines animale. Pharm Méd Trad Afr, 2001 ; 11:113- 122.

Bayer E, Buttler KP, Finkenzeller X, Grau J. 2009.Guide de la flore méditerranéenne: Caractéristiques, habitats, distribution et particularités de 536 espèces.éd. nature Delachaux et Niestlé. p. 94.
Benhammou N, Bekkara AF, Panovska KT. Antioxidant and antimicrobial activities of the Pistacia lentiscusand Pistacia atlantica extracts. Afri J Pharm Pharmacol 2008; 2: 22-28.

Clevenger JF. Apparatus for the determination of volatile oil. J Am Pharm Assoc 1928; 17: 341-6.

Clinical and Laboratory Standards Institute (CLSI). 2007. Performance standards for antibacterial susceptibility testing; Seventeenth information supplement M 100- S17;27 (1): 81-86.

Daferera D, Pappas C, Tarantilis PA, Polisiou M. Quantitative analysis of pinène and myrcène in mastic gum oil using FT-Raman spectroscopy. Food Chemistry 2002; 77: 511-515.

De Pooter HL, Schamp NM, Aboutabl EA, El Tohamy SF, Doss SL. Essential oils from the leaves of three Pistacia species grown in Egypt. Flavour and Fragrance journal 1991; 6: 229- 232.

Derwich E, Manar A, Benziane Z, Boukir A. GC/MS Analysis and In vitro Antibacterial Activity of the Essential Oil Isolated from Leaf of Pistacia lentiscus growing in Morocoo. World Applied Sciences Journal2010; 8 (10): 1267-1276.

Djenane D, Yangüela J, Montañés L, Djerbal M, Roncalés P. Antimicrobial activity of Pistacia lentiscus and Saturejamontana essential oils against Listeria monocytogenes CECT 935 using laboratory media: Efficacy and synergistic potential in minced beef. Food Control 2011; 22 1046-1053.

Durua, M E, Cakirb A, Kordalic S, Zenginc H, Harmandara M, Izumid $\mathrm{S}$ et al. Chemical composition and antifungal properties of essential oils of three Pistacia species. Fitoterapia 2003; 74: 170-176.

Hafsé M, Fikri Benbrahim K, Saidi A, Farah A. Volatile Components and Antibacterial Profile of Essential Oils Extracted from Leaves and Twigs of Pistacia lentiscus L.. British Microbiology Research Journal2013; 3(4): 602-611.

Hemaiswarya S, Kruthiventi AK, Doble M. Synergism between natural products and antibiotics against infectious diseases. Phytomedicine 2008; 15: 639-652.

Hmamouchi M. 1999. Les plantes médicinales et aromatiques marocaines : utilisations traditionnelles, marchés, biologies, écologies, chimie, pharmacologie, toxicologie, lexiques Imp. de Fédala. p.140.

Kasrati A, Alaoui JC, Fadli M, Bekkouche K, Hassani L, Wohlmuth $\mathrm{H}$ et al. Antioxidative activity and synergistic effect of Thymus saturejoides Coss. essential oils with cefixime against selected food-borne bacteria. Industrial Crops and Products 2014; 61: 338-344.

Mann CM, Markham JL. A new method for determining the minimum inhibitory concentration of essential oils. Journal of Applied Microbiology 1998; 84: 538-544.

Murray PR, Baron EJ, Jorgensen JH, Landry ML, Pfaller MA. 2007. Manual of clinical microbiology, 9th ed. ASM Press, Washington, D.C: $1152-1172$.

Trombetta D,Castelli F, Sarpietro MG, Venuti V, Cristani M, Daniele C, Saija A, Mazzanti G, Bisignano G. Mechanisms of antibacterial action of three monoterpenes. Antimicrob. Agents Chemother 2005; 49: 2474-2478.

Turgis $\mathrm{M}, \mathrm{Vu} \mathrm{KD}$, Dupont $\mathrm{C}$, Lacroix M. Combined antimicrobial effect of essential oils and bacteriocins against foodborne pathogens and food spoilage bacteria. Food Research International 2012; 48: 696-702.

Zrira S, Benjilali B, Lamaty G. Effet duséchage à l'air libre des feuilles d'E. camaldulensissur le rendement et la composition de l'huile essentielle. Actes Inst Agron Veto- Maroc,1995; 15 (4) : 27-35.

\section{How to cite this article:}

Taoufik Haloui, Abdellah Farah, Mounyr Balouiri, Marwa Chraibi, Mouhcine Fadil, Kawtar Fikri Benbrahim, Aziz Belrhiti Alaoui. Bacteriostatic and Bactericidal Profile of Leaves and Twigs Essential oils of Moroccan Pistacia lentiscus L. J App Pharm Sci, 2015; 5 (06): 050-053. 